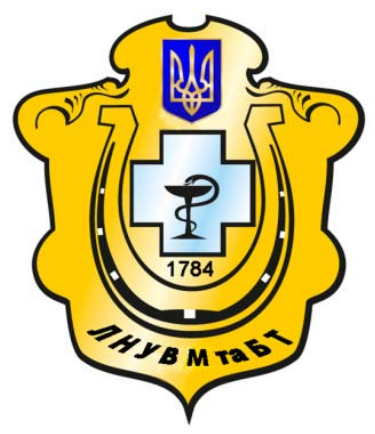

Науковий вісник Львівського національного університету ветеринарної медицини та біотехнологій імені С.3. Гжицького

Scientific Messenger of Lviv National University of Veterinary Medicine and Biotechnologies named after S.Z. Gzhytskyj

doi:10.15421/nvlvet6609

ISSN 2413-5550 print

ISSN 2518-1327 online

$\underline{\text { http://nvlvet.com.ua/ }}$

УДК 619:616.36/.6-071/085:616.993.192.6:636.7

\title{
Показники гемопоезу собак за бабезіозу
}

\author{
І.Ю. Горальська, О.В. Пінський \\ veremchuk_yaruna@ukr.net \\ Житомирський національний агроекологічний університет, \\ вул. Корольова, 39, м. Житомир, 10025, Украӥна
}

\begin{abstract}
У статті подані результати досліджень стану гемопоезу собак за гострого перебігу бабезіозу. 3 'ясовано, щзо за руйнування еритроцитів Babesia canis в процесі розвитку захворювання розвивається регенераторно-макроцитарна анемія, щяо супроводжується олігоцитемією, олігохромемією, макроцитозом, ретикулоцитозом, тромбоцитопенією, підвищенням ШОЕ. При цьому зменшення кількості еритрочитів переважало над зниженням вмісту гемоглобіну, шо й дає підстави вважати такий процес гемолітичним. Вже на периих етапах розвитку хвороби виявляється пойкілочитоз з наявністю ехіноцитів, акантоцитів та стоматоцитів. За третьої стадії хвороби в руслі крові з'являлися уривки еритроцитів (шизоцити) та їх базофільна зернистість. Свідчення про високу потребу організму в кисні за гемолізу підтверджується зростаючою кількістю ретикулочитів, ще посилено вимиваються із кісткового мозку в периферійну кров. Зниження кількості тромбоцитів у крові собак за гострого перебігу бабезіозу відбувається за посиленого їх руйнування та зменшення продукиї внаслідок спленомегалії за рахунок секвестрації (депонування) иих клітин крові. За бабезіозу у собак розвивається порушення обміну ферумовмістимих пігментів (гемохроматоз), щя підтверджується гіперсидеремією та може свідчити про відкладання феруму у печіниі, нирках, м'язах.
\end{abstract}

Ключові слова: бабезіоз, собаки, гемолітична анемія, гематологічні дослідження, еритроцити, гемоглобін, гематокритна величина, тромбочити, кістковий мозок, гіпоксія.

\section{Показатели гемопоэза у собак при бабезиозе}

\author{
И.Ю. Горальская, Пинский О.В. \\ veremchuk_yaruna@ukr.net
}

Житомирский национальный агроэкологический университет, ул. Королева, 39, г. Житомир, 10025, Украина

В статье представлены результаты исследований состояния гемопоэза собак при остром течении бабезиоза. Установлено, что при разрушении эритрочитов Babesia canis в процессе развития заболевания развивается регенераторномакроцитарная анемия, что сопровождается олигоцитемией, олигохромемией, макроцитозом, ретикулоцитозом, тромбоциитопенией, повышением СОЭ. При этом уменьшение количества эритроцитов преобладало над снижением содержания гемоглобина, что и дает основания считать такой процесс гемолитическим.

Уже на первых этапах развития болезни диагностируется пойкилоцитоз с наличием ехиноцитов, акантоцитов и стоматоцичтов. В третьей стадии болезни в русле крови появлялись отрывки эритроцитов (шизоциты) и их базофильная зернистость. Свидетельство о высокой потребности организма в кислороде при гемолизе подтверждается растущим количеством ретикулочитов, что усиленно вымываются из костного мозга в периферическую кровь.

Снижение количества тромбоцитов в крови собак при остром течении бабезиоза происходит при усиленном их разрушении и уменьшении продукции вследствии спленомегалии за счет секвестрации (депонирования) этих клеток крови.

При бабезиозе у собак развивается нарушение обмена ферумвместимих пигментов (гемохроматоз), что подтверждается гиперсидеремией и может свидетельствовать об отложении железа в печени, почках, мышиах.

Ключевые слова: бабезиоз, собаки, гемолитическая анемия, гематологические исследования, эритрочиты, гемоглобин, гематокритная величина, тромбоциты, костный мозг, гипоксия.

\section{Citation:}

Goralska, I., Pinsky, O. (2016). Indicators hematopoiesis dog for babesiosis. Scientific Messenger LNUVMBT named after S.Z. Gzhytskyj, 18, 2(66), $40-43$. 


\title{
Indicators hematopoiesis dog for babesiosis
}

\author{
I. Goralska, O. Pinsky \\ veremchuk_yaruna@ukr.net \\ Zhytomyr National Agroecological University, \\ Korolova Str., 39, Zhytomyr, 10025, Ukraine
}

The article presents the results of research on the state of hematopoiesis dogs acute babesiosis course. It was found that for the destruction of red blood cells Babesia canis in the development of the disease develops regenerative, macrocytic anemia, accompanied olihotsytemiyeyu, olihohromemiyeyu, macrocytosis reticulocytosis, thrombocytopenia, increased ESR. This reduction in the number of red blood cells prevailed over reduction of hemoglobin, which suggests a hemolytic process.

Already in the early stages of the disease is detected the presence of poikilocytosis ehinotsytiv, akantotsytiv and stomatotsytiv. In the third stage of the disease in the bloodstream appear fragments of erythrocytes (shyzotsyty) and their basophilic stippling.

Evidence of the high requirement of oxygen by hemolysis is confirmed by the increasing number of reticulocytes, which strongly leached from bone marrow into peripheral blood.

Reducing the number of platelets in the blood flow of dogs for acute babesiosis is strengthened by their destruction and reduction of production due to splenomegaly due to sequestration (deposit) of these blood cells.

For babesiosis in dogs develop metabolic ferumovmistymyh pigments (hemochromatosis), confirmed hipersyderemiyeyu and may indicate a postponement of iron in the liver, kidneys and muscles.

Key words: babesiosis, dogs, haemolytic anemia, hematological studies, erythrocytes, hemoglobin, hematocrit value, platelets, bone marrow, hipoksiya.

\section{Вступ}

За останні декілька десятків років значно погіршилась картина захворюваності бабезіозом. Хворіють не тільки собаки мисливських та службових порід, але й безпорідні та метиси.

На сьогодні достатньо широко вивчено поширення цього захворювання собак в Україні. 3'ясовано патогенний вплив збудника та характер імунної відповіді організму тварин на інвазію, розроблено та запропоновано схеми профілактики та лікувальних заходів (Georgiu and Rasstrigin, 2002; Budovskij, 2000).

Особливістю патогенезу захворювання $є$ розмноження збудника бабезіозу в організмі сприйнятливої тварини в еритроцитах капілярів внутрішніх органів, потім в еритроцитах русла крові. Виділені при цьому продукти обміну паразитів викликають порушення функції органів кровотворення, порушується кровообіг тощо.

Провідна роль в патогенезі відводиться розпаду еритроцитів і як наслідок розвитку анемії. Руйнування червоних клітин крові відбувається в печінці, що призводить до появи в крові вільного гемоглобіну, який виділяється з сечею в незміненому вигляді або у вигляді уробіліногену (Budovskij, 2000; Kondrahin et al., 2004).

Таким чином, за бабезіозу зміни функцій системи кровообігу, особливо морфологічного складу крові, носять адаптаційний характер.

Зважаючи, що кров є діагностичним тестом захворювань різного генезу, а кровотворні органи надзвичайно чутливі до впливу різноманітних фізіологічних чинників, а особливо, за патологічного впливу на організм, актуальним залишається вивчення морфологічного складу крові собак за бабезіозу.

\section{Матеріал і методи досліджень}

Об'єктом для дослідження були собаки порід німецька і середньоазійська вівчарки та ротвейлери віком від 18 міс. до 8 років. Для проведення експериментальних досліджень були сформовані чотири групи собак: перша $(\mathrm{n}=16)$ - 3 клінічними ознаками та симптомами гострого перебігу бабезіозу у перші дві доби прояву (перша стадія); друга (n = 13) - на 3-4 добу (друга стадія); третя $(\mathrm{n}=16)$ - на 5-6 добу (третя стадія); четверта $(\mathrm{n}=20)$ - клінічно здорові.

Стан гемопоезу оцінювали за загальною кількістю еритроцитів (пробірковим методом) і ретикулоцитів (виражали у процентах до 1 тис. еритроцитів у мазках крові, забарвлених $0,5 \%$ розчином метиленового синього) і тромбоцитів (за Brecher G. et al.) - у камері 3 сіткою Горяєва; гематокритну величину - мікрометодом у модифікації Й. Тодорова; ШОЕ - за Панченковим; вміст гемоглобіну в крові визначали геміглобінціанідним методом; феруму в плазмі крові - за реакцією з ферозином; насиченість еритроцитів гемоглобіном (MCH), середній об'єм еритроцитів (MCV) та колірний показник визначали шляхом розрахунків.

\section{Результати та їх обговорення}

Вивчення показників периферійної крові за бабезіозу у собак $є$ основою діагностичного дослідження, яке має вирішальне значення в постановці діагнозу та подальшому спостереженні за перебігом хвороби.

Дослідженнями мазків крові методом світлової мікроскопії, забарвлених за методом РомановськогоГімзи, виявляли ураження еритроцитів бабезіями, яке зростало в геометричній прогресії. Так, інтенсивність інвазіï Babesia canis становила 2 - 4\% у перші дві доби захворювання. Далі відсоток бабезій зростав до $8 \%$ у хворих з тривалістю хвороби 3 - 4 дні та до $15 \%$ на 5 - 6 день.

За бабезіозу у собак на перших етапах розвитку хвороби виявлявся пойкілоцитоз з наявністю ехіноцитів та акантоцитів (сферичні зірчасті клітини), стоматоцитів (пелорій у вигляді щілини). Ознакою третьої стадії хвороби були шизоцити (уривки еритроцитів) та базофільна зернистість еритроцитів. 
За морфологічного дослідження крові у собак при перших проявах бабезіозу спостерігалася олігоцитемія. Кількість еритроцитів на початку захворювання у середньому становила 4,6 $\pm 0,20$ Т/л, що на $33 \%$ менше, ніж у клінічно здорових $(6,9 \pm 0,13$ Т/л). На $3-$ 4 добу клінічного прояву хвороби їх кількість продовжувала знижуватися i в середньому становила 3,5 \pm 0,17 Т/л $(\operatorname{Lim} 2,5-4,6)$. За третьої стадії бабезіозу кількість «червоних кров'яних» тілець була на критичній межі - 2,5 $\pm 0,16$ T/л $(\operatorname{Lim} 1,6-3,5)$. У частини хворих олігоцитемія була в межах 1,6 - 2,0 Т/л.

Вміст гемоглобіну у крові клінічно здорових собак у середньому становив $165,7 \pm 2,98$ г/л $(\operatorname{Lim} 150,0$ 196,3). У перші дні прояву хвороби його уміст був нижчим за норму у 94\% хворих собак і в середньому становив 117,2 \pm 4,98 г/л $(\operatorname{Lim} 90,0-151,0)$. Подальше зниження цього дихального пігменту крові спостерігали з поглибленням патологічного процесу: так на 3 4 добу хвороби (друга стадія) вміст гемоглобіну становив 95,5 $\pm 4,17$ г/л $(\operatorname{Lim} 59,0-118,0)$, а на 5-6 добу - 70,2 \pm 4,44 г/л ( $\operatorname{Lim} 45,2-96,2)$.

Таким чином, аналізуючи отримані дані, можна сказати, що кількість еритроцитів і вміст гемоглобіну 3 початку захворювання зменшувалась відносно контролю по групах на 33,$3 ; 49,5$ та $63,4 \%$ і на 29,$3 ; 42,4$ та $57,6 \%$ відповідно. Тобто, руйнування еритроцитів переважало над зниженням вмісту гемоглобіну, що й дає підстави вважати такий процес гемолітичним, анемію - гемолітичною, спричинену надмірним руйнуванням еритроцитів Babesia canis.

Кількість ретикулоцитів (поліхроматофільних еритроцитів) відображає швидкість регенерації, продукцію еритроцитів кістковим мозком, а їх підрахунок має значення для оцінки ступеня активності еритропоезу (Georgiu and Rasstrigin, 2002; Antonjuk et al., 2006; Mejer and Harvi, 2007). Ретикулоцити дещо більші за еритроцити, мають меншу концентрацію гемоглобіну, ніж зрілі еритроцити. У крові клінічно здорових тварин їх кількість становила в середньому $1,2 \pm 0,09 \%$; у перші дні захворювання - 2,8 $\pm 0,21 \%$. Із прогресуванням хвороби їх кількість збільшувалася до $5,6 \pm 0,47 \%(\operatorname{Lim} 3-8)$ на 3-4-ту та до $11,1 \pm$ $0,54 \%$ ( $\operatorname{Lim} 7-15)$ на 5 - 6-ту добу захворювання.

Гематокритна величина $є$ допоміжним критерієм при визначенні ряду показників у гематології, вона залежить від загальної кількості еритроцитів та їх середнього об'єму. За першої стадії іiі значення в середньому становили $37,2 \pm 1,46 \%$; другої - 29,7 $\pm 1,06$ і за третьої - 22,6 $\pm 1,37 \%$. Виявили позитивну кореляцію між кількістю ретикулоцитів та гематокритною величиною на початкових стадіях перебігу бабезіозу $(\mathrm{r}=0,58)$. Зменшення гематокритної величини зазвичай веде до підвищення концентрації гемопоетину в плазмі, який зумовлює збільшення кількості ретикулоцитів, посилене вимивання їх із кісткового мозку в периферійну кров та $є$ свідченням високої потреби організму в кисні (Kondrahin et al., 2004; Bazhibina et al., 2005).

Для характеристики гемолітичної анемії важливо знати, як змінюється вміст гемоглобіну в еритроцитах, їх об'єм та насиченість кров'яним пігментом.
Вміст гемоглобіну в одному еритроциті (MCH) у клінічно здорових собак становив у середньому $24,1 \pm$ 0,24 пг. У хворих - незалежно від стадії бабезіозу $M C H$ підвищувався. Із поглибленням патології у хворих собак збільшується $M C V:$ : $81,5,0 \pm 2,17$ за першої до $90,5 \pm 2,97$ мкм $^{3}$ за третьої стадії бабезіозу. Підвищення $M C H$ корелювало з макроцитозом $(\mathrm{r}=0,39)$ у перші два дні хвороби та до $\mathrm{r}=0,7$ - за третьої стадії. КП у хворих собак усіх груп не виходив за межі фізіологічних коливань $(0,85-1,15)$.

У хворих собак виявляли тромбоцитопенію. Якщо у клінічно здорових собак кількість тромбоцитів становила $381,5 \pm 16,36$ (260 - 510), то за першої стадії патологічного процесу їх було 239,4 $\pm 14,24$ Г/л, тобто менше на $37,3 \%$. У хворих за другої та третьої стадій захворювання кількість кров'яних пластинок була ще нижчою - 185,4 $\pm 13,62$ та 178,1 \pm 13,94 Г/л відповідно. Зниження кількості тромбоцитів у крові собак за гострого перебігу бабезіозу відбувається внаслідок посиленого їх руйнування, зменшення продукції за рахунок секвестрації (депонування) цих клітин крові внаслідок спленомегалії.

Однією із важливих фізичних властивостей крові $€$ швидкість осідання еритроцитів (ШОЕ). Цей показник свідчить про дзета-потенціал еритроцитів (Georgiu and Rasstrigin, 2002; Mejer and Harvi, 2007). Зменшення його призводить до посиленої агломерації еритроцитів і підвищення ШОЕ. У хворих за першої стадії бабезіозу ШОЕ у середньому становила $6,2 \pm$ 0,68 мм/год, що вірогідно вище, ніж у клінічно здорових (p < 0,001). 3 поглибленням патології підвищення ШОЕ було ще більш показовим. Зокрема, за другої стадії прояву захворювання його величина у середньому становила 23,2 \pm 4,96 мм/год, що в 11,3 рази більше, ніж у здорових ( $<<0,001)$. Підвищене ШОЕ встановлене у $85 \%$ хворих.

За третьої стадії бабезіозу ШОЕ була підвищеною в усіх тварин і в середньому становила $31,9 \pm 6,51$ мм/год, що в 15,6 разів більше, ніж у здорових $(\mathrm{p}<0,001)$, при цьому найбільш високі значення ШОЕ були у собак за анемії, кахексії, гепато- та спленомегалії.

За бабезіозу розвивається ендогенний сидероз, який виникає в результаті підвищеного руйнування гемоглобіну.

Уміст феруму в сироватці крові вказує на рівень транспортної його форми в крові, яка зв'язана 3 трансферином. Кількість мікроелементу в сироватці крові хворих собак за першої стадії бабезіозу в середньому становила 24,0 \pm 0,86 мкмоль/л, тобто була вище максимальної норми $(21,5)$. У собак за другої та третьої стадій захворювання рівень феруму був ще більшим 29,6 \pm 0,92 і 35,8 \pm 0,64 мкмоль/л відповідно. Тобто, гіперсидеремія за бабезіозу може свідчити про відкладання феруму у печінці, нирках, м'язах, що призводить до виникнення гемохроматозу (порушення обміну ферумовмістимих пігментів).

\section{Висновки}

У собак за бабезіозу виявили олігоцитемію, олігохромемію, макроцитоз, ретикулоцитоз, тромбоцитопенію, підвищення ШОЕ. 
У результаті руйнування гемоглобіну розвивається ендогенний сидероз, на що вказує підвищений уміст феруму в сироватці крові. Це може спричинити відкладання мікроелемента в печінці і нирках та розвиток гемохроматозу. Отже, у собак за бабезіозу розвивається регенераторно-макроцитарна анемія.

Перспективи подальших досліджень. Вважаємо, що подальші дослідження повинені бути направлені на проведення вивчення токсичного впливу розмноження Babesia canis та руйнування еритроцитів на кістковий мозок собак.

\section{Бібліографічні посилання}

Budovskij, A.V. (2000). Naibolee rasprostranennye kroveparazitarnye bolezni sobak i koshek (jetiologija, patogenez, diagnostika, profilaktika, lechenie). Veterinarija. 3, 31-36 (in Russian).
Georgiu, H., Rasstrigin, A. (2002). Gemoliticheskaja anemija pri babezioze sobak. Mater. 10-j mezhd. konf. protozoologov. M., 38-39 (in Russian).

Antonjuk, G.A., Sologub, L.I., Snityns'kyj, V.V., Babych, N.O. (2006). Zalizo $\mathrm{v}$ organizmi ljudyny i tvaryn (biohimichni, imunologichni ta ekologichni aspekty). L'viv (in Ukrainian).

Mejer, D., Harvi, Dzh. (2007). Veterinarnaja laboratornaja medicina. Interpretacija i diagnostika [per. s angl.]. M.: Sofion (in Russian).

Bazhibina, E., Korobov, A., Sereda, S. (2005). Saprykin V.Metodologicheskie osnovy ocenki klinikomorfologicheskih pokazatelej krovi domashnih zhivotnyh. M., Akvarium (in Russian).

Kondrahin, I.P., Arhipov, A.V., Levchenko, V.I. (2004). Metody veterinarnoj klinicheskoj laboratornoj diagnostiki: spravochnik. M.: Kolos (in Russian).

Стаття надійшла до редакиії 26.09.2016 